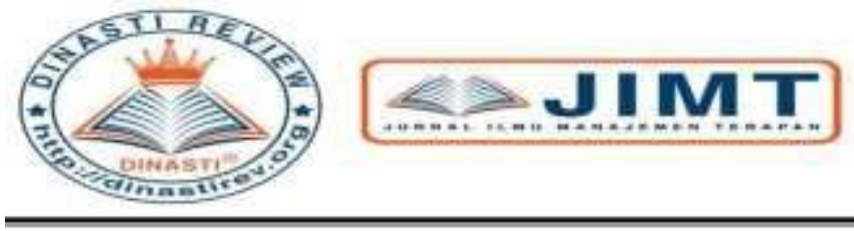

+62 878-9658-6407

087896586407

https://dinastirev.org/JIMT editor@dinastirev.org

\title{
PENGARUH DISIPLIN KERJA, IKLIM ORGANISASI DAN KOMITMEN ORGANISASI TERHADAP PRODUKTIVITAS KERJA GURU
}

\author{
${ }^{1)}$ Desi Ariani, ${ }^{2)}$ Ika Puji Saputri, ${ }^{3)}$ Indri Astiana Suhendar \\ ${ }^{1)}$ Fakultas Ekonomi dan Bisnis, Universitas Mercu Buana, Jakarta, Indonesia \\ ${ }^{2,3)}$ Fakultas Ekonomi dan Bisnis, Universitas Dian Nusantara, Jakarta, Indonesia
}

\begin{tabular}{|c|c|}
\hline $\begin{array}{l}\text { ARTICLE INFORMATION } \\
\text { Received: 23/01/2020 } \\
\text { Revised: 10/02/2020 } \\
\text { Issued: 29/02/2020 } \\
\text { (filled in by Editor) } \\
\text { Corresponding Author: } \\
\text { desiariani182@gmail.com } \\
\text { ika.puji.saputri@undira.ac.id } \\
\end{array}$ & $\begin{array}{l}\text { Abstrak: Tujuan utama dari penelitian ini adalah untuk } \\
\text { menguji dan menganalisis } \\
\text { pengaruh disiplin kerja, iklim organisasi dan komitmen } \\
\text { organisasi terhadap produktivitas kerja pada Sekolah } \\
\text { Dasar Islam Assidiqiyah Ciledug. Data dalam penelitian } \\
\text { diperoleh dari } 56 \text { responden yang merupakan guru di } \\
\text { Sekolah Dasar Islam Assidiqiyah Ciledug. Analisis data } \\
\text { dalam penelitian ini menggunakan metode alternatif dari } \\
\text { structural equation modeling (SEM) yaitu partial least } \\
\text { square (PLS). Tahap pertama dalam penelitian ini untuk } \\
\text { menguji validitas pertanyaan setiap variabel berikut } \\
\text { dengan reliabilitasnya. Tahap kedua menguji hubungan } \\
\text { antara disiplin kerja, iklim organisasi dan komitmen } \\
\text { organisasi terhadap produktivitas kerja. Hasil dari } \\
\text { penelitian ini menyatakan bahwa variabel disiplin kerja, } \\
\text { iklim organisasi dan komitmen organisasi berpengaruh } \\
\text { positif dan signifikan terhadap produktivitas kerja. }\end{array}$ \\
\hline
\end{tabular}

\section{PENDAHULUAN}

Sumber daya manusia merupakan aset utama bagi perusahaan. Sumber daya yang memiliki akal, perasaan, keinginan, kemampuan, dan ketrampilan. Semua potensi sumber daya manusia sangat berpengaruh terhadap upaya dalam pencapaian tujuan sebuah organisasi. Sehingga antara organisasi dan individu yang ada didalamnya merupakan suatu talenta yang tidak biasa di pisahkan (Nengsih, 2015). Karena peranan sumber daya manusia sangat penting bagi suatu organisasi. Maka keberhasilan organisasi tergantung pada sumber daya yang dimilikinya dan bagaimana organisasi tersebut dapat meningkatkan produktivitas yang dimilikinya. Sumber daya manusia yang produktif akan dapat menyelesaikan tugasnya dengan tepat, cepat, dan memiliki komunikasi yang baik dengan atasan dan teman sejawat (Hastuti, Dewi, Suhardini, 2016). Mukhyi dan Hudiyanto (2016) menyatakan bahwa hakikat sumber daya manusia setiap organisasi atau perusahaan, khususnya pada lembaga pendidikan yaitu dengan adanya sumber daya manusia sebagai tenaga kerja. Oleh sebab itu, yang 
dimaksud dengan sumber daya manusia adalah tenaga kerja pada suatu organisasi. Dari pendapat tersebut jelas bahwa sumber daya manusia adalah tenaga kerja yang menduduki suatu posisi atau sekelompok orang yang mempunyai tanggung jawab untuk melaksanakan tugas atau pekerjaan pada suatu organisasi tertentu.

Dalam proses peningkatan kualitas sumber daya manusia tenaga guru pada dunia pendidikan memegang peran yang sangat penting dengan melaksanakan tugas profesinya guru senantiasa dituntut untuk mampu meningkatkan kemampuan yang berkaitan dengan produktivitas kerjanya sebagai seorang guru. Menurut Fatah (2015) menyatakan bahwa produktivitas adalah hasil kerja dari seseorang atau organisasi yang merupakan penampilan atau performance dari seseorang atau organisasi tertentu secara keseluruhan. Dan Pratiwi (2016) mendefinisikan kinerja seorang guru juga harus disertai dengan produktivitas kerja sebagai seorang pendidik yang profesional.

Produktivitas kerja guru dapat ditinjau dari tugas guru yang tertuang dalam tugas pokok dan fungsi guru. Tugas pokok dan fungsi guru adalah membantu dan bertanggung jawab kepada kepala sekolah dalam kegiatan belajar mengajar, meliputi: (a) membuat kelengkapan mengajar dengan baik dan lengkap; (b) melaksanakan kegiatan pembelajaran; (c) melaksanakan kegiatan penilaian proses belajar, ulangan harian, ulangan umum dan ujian akhir; (d) melaksanakan analisis hasil ulangan harian; (e) menyusun dan melaksanakan program perbaikan dan pengayaan; (f) mengisi daftar nilai anak didik; (g) melaksanakan kegiatan membimbing (pengimbasan pengetahuan) kepada guru lain dalam proses pembelajaran; (h) membuat alat pelajaran; (i) menumbuh kembangkan sikap menghargai karya seni; (j) mengikuti kegiatan pengembangan dan pemasyarakatan kurikulum; (k) melaksanakan tugas tertentu di sekolah; (l) mengadakan pengembangan program pembelajaran; (m) membuat catatan tentang kemajuan hasil belajar anak didik; (n) mengisi dan meneliti daftar hadir sebelum memulai pelajaran; (o) mengatur kebersihan ruang kelas dan sekitarnya dan mengumpulkan dan menghitung angka kredit untuk kenaikan pangkat (UUGD, 2011).

Adapun untuk meningkatkan produktivitas perlu diperhatikan kedisiplinan kerja dalam organisasi atau perusahaan tersebut. Didit (2017) mendefinisikan disiplin kerja sebagai sikap, perilaku, dan tindakan pengaturan yang sesuai dari organisasi dalam bentuk tertulis atau tidak. Oleh karena itu, jika organisasi telah membuat peraturan yang ditaati oleh karyawan, maka disiplin tersebut telah mampu menetapkan disiplin kerja sebagai alat bagi manajer untuk berkomunikasi dengan karyawan, sehingga dapat mengubah perilaku untuk meningkatkan kesadaran dan kemauan untuk memenuhi semua peraturan perusahaan (Rival, 2017).

Demi mencapai produktivitas yang tinggi, juga perlu untuk mengupayakan terciptanya iklim organisasi yang baik. Iklim organisasi menurut Owens (2016) mengemukakan bahwa iklim organisasi adalah suatu studi tentang persepsi individu terhadap berbagai macam aspek lingkungan yang merefleksikan nilai dan sistem keyakinan organisasi. Sedangkan menurut Litwin (2016) iklim organisasi sebagai suatu set dari sifat yang dapat diukur dan suatu lingkungan organisasi yang didasarkan pada konsepsi secara kolektif dari orang-orang yang hidup dan bekerja dalam lingkungan organisasi.

Selain itu dalam meningkatkan produktivitas perlu diperhatikan komitmen antara karyawan dengan organisasi. Bila semua karyawan yang berada dalam suatu organisasi dapat berkomitmen maka tujuan dari organisasi tersebut akan tercapai. Menurut Winner dan Sopian (2014) komitmen organisasi adalah dorongan dalam diri individu untuk membuat sesuatu agar dapat menunjang keberhasilan organisasi dengan tujuan dan lebih mengutamakan 
kepentingan organisasi.

Penelitian ini dilakukan di Sekolah Dasar Islam yang berlokasi dikawasan Jalan Hos Cokroaminoto No 2, Sudimara Barat, Kec. Ciledug, Kota Tangerang Prov. Banten. Yayasan Pendidikan Islam Assidiqiyah adalah salah satu dari sekian banyak Sekolah Dasar Islam yang berusaha meningkatkan produktivitas tenaga pendidik sehingga membutuhkan sumber daya manusia yang berkualitas. Yang diharapkan dapat memberikan nilai tambah dalam pemanfaatan karyawan secara stategis terhadap program kerja perusahaan.

Adapun pendekatan strategis dan komprehensif mencakup bidang - bidang dalam ruang lingkup salah satunya ialah absensi (Hidayat, Sugiharjo, Parashakti, 2019). Kondisi guru yang ada saat ini pada Sekolah Dasar Islam Assidiqiyah dijumpai masih adanya guru yang sering datang terlambat, kadang tidak masuk dan sering meninggalkan jam mengajar tanpa keterangan, bersikap pasif pada pekerjaan, dan masih ada beberapa guru yang tidak tepat waktu dalam menyelesaikan pekerjaannya.

Permasalahan dalam penelitian ini adalah: (1) Apakah disiplin kerja berpengaruh signifikan terhadap produktivitas kerja guru di Sekolah Dasar Islam Assidiqiyah Ciledug?; (2) Apakah iklim organisasi berpengaruh signifikan terhadap produktivitas kerja guru di Sekolah Dasar Islam Assidiqiyah Ciledug?; (3) Apakah komitmen organisasi berpengaruh signifikan terhadap produktivitas kerja guru di Sekolah Dasar Islam Assidiqiyah Ciledug ?

\section{KAJIAN PUSTAKA}

\section{Produktivitas Kerja}

Menurut Yusuf (2015) menyatakan bahwa produktivitas merupakan sikap mental yang selalu berusaha dan mempunyai pandangan bahwa suatu kehidupan hari ini lebih baik dari hari kemarin dan hari esok lebih baik dari hari ini. Produktivitas tenaga kerja merupakan perbandingan antara hasil yang dicapai dengan pasar tenaga kerja per satuan waktu dan sebagai tolak ukur jika ekspansi dan aktivitas dari sikap sumber yang digunakan selama produktivitas berlangsung dengan membandingkan jumlah yang dihasilkan dengan setiap sumber daya yang dipergunakan. Jadi produktivitas kerja adalah ukuran yang menunjukkan pertimbangan antara input dan output yang dikeluarkan perusahaan serta peran tenaga kerja yang dimiliki persatuan waktu.

Sedangkan menurut Prabu (2015) produktivitas adalah hasil kerja secara kualitas dan kuantitas yang dicapai oleh seseorang dalam melaksanakan tugasnya sesuai dengan tanggung jawab yang diberikan kepadanya.

Dimensi dan indikator Produktivitas Kerja. Menurut Sedarmayanti (2015) dimensi produktivitas kerja dapat diuraikan menjadi berikut:

a. Efisiensi. Ukuran yang menunjukan dimana sumber-sumber daya yang digunakan dalam proses produksi untuk menghasilkan output yang merupakan karakteristik proses yang mengukur performansi aktual dari sumber daya relatif terhadap standar yang ditetapkan.

b. Efektivitas. Melaksanakan sesuatu yang benar dalam memenuhi kebutuhan organisasi berkaitan dengan pencapaian unjuk kerja yang maksimal, dalam arti pencapaian target yang berkaitan dengan kualitas, kuantitas dan waktu.

c. Kualitas

Mutu yang harus dihasilkan baik atau tidaknya. Hal ini dipengaruhi oleh kecakapan dan pengalaman kerja seseorang.

\section{Disiplin Kerja}

Disiplin kerja adalah sikap manajer dapat berkomunikasi dengan karyawan sehingga 
mereka bersedia untuk mengubah perilaku serta upaya untuk meningkatkan kesadaran dan kesediaan seseorang untuk mematuhi semua aturan perusahaan dan norma-norma sosial yang berlaku (Rivai, 2015).

Menurut Sinungan (2015) disiplin kerja sebagai sikap mental yang tercermin dalam tindakan atau perilaku individu, kelompok atau komunitas dalam bentuk kepatuhan atau kepatuhan terhadap peraturan yang ditetapkan oleh Pemerintah atau etika, norma, dan aturan yang berlaku di masyarakat untuk tujuan tertentu.

Menurut Siagian (2015) juga berpendapat bahwa disiplin adalah bentuk pelatihan karyawan yang bertujuan untuk meningkatkan dan membangun pengetahuan, sikap dan perilaku karyawan, sehingga karyawan secara sukarela mencari pekerjaan dengan karyawan lain.

Dimensi dan indikator Disiplin Kerja

Menurut Rivai, Sagala (2014) dimensi disiplin kerja dapat diuraikan sebagai berikut:

a. Kehadiran: (1) Karyawan meminta ijin apabila terlambat datang ke kantor; (2) Karyawan meminta ijin apabila tidak dapat masuk kerja.

b. Ketaatan pada peraturan kerja: (1) Karyawan tidak membawa pulang peralatan perusahaan; (2) aryawan bersedia dikenakan sanksi sesuai dengan peraturan jika melanggar peraturan tersebut.

a. Ketaatan pada standar kerja: (1) Karyawan bekerja sesuai dengan prosedur yang telah ditetapkan perusahaan; (2) Karyawan melakukan semua pekerjaan sesuai dengan standar kerja yang ditentukan perusahaan.

b. Tingkat kewaspadaan tinggi: (1) Karyawan selalu fokus dalam bekerja; (2) Karyawan berhati-hati dalam setiap menggunakan peralatan perusahaan.

c. Bekerja Etis: (1) Karyawan bersikap sopan selama berada didalam kantor; (2) Karyawan memiliki etika yang baik selama berada didalam kantor

\section{Iklim Organisasi}

Menurut Sukardiyono (2017) iklim organisasi adalah studi sistematis mengenai tugas, kewajiban, dan tanggung jawab dari suatu pekerjaan, serta pengetahuan, kemampuan, dan keahlian yang dibutuhkan untuk mengerjakan pekerjaan tersebut. Iklim organisasi adalah titik awal untuk hampir semua fungsi personalia dan analisis ini sangat penting untuk mengembangkan cara penilaian sumber daya manusia. Dengan demikian jelas bahwa iklim organisasi sangat penting dilakukan organisasi agar dapat memberikan gambaran yang jelas tentang pekerjaan yang akan diberikan kepada para pegawai.

Menurut Mutaqin (2017) dalam penelitiannya bahwa setiap organisasi akan memiliki iklim organisasi yang berbeda. Keanekaragaman pekerjaan yang dirancang di dalam organisasi, atau sifat individu yang ada akan menggambarkan perbedaan tersebut. Semua organisasi tentu memiliki strategi dalam memanajemen sumber daya manusia (SDM). Iklim organisasi yang terbuka memacu karyawan untuk mengutarakan kepentingan dan ketidakpuasan tanpa adanya rasa takut akan tindakan balasan dan perhatian. Ketidakpuasan seperti itu dapat ditangani dengan cara yang positif dan bijaksana.

Dimensi dan indikator Iklim Organisasi. Menurut Brown dan Leigh (2013) mengatakan bahwa untuk mengukur iklim organisasi terdapat enam dimensi yang diperlukan, yaitu:

a. Dukungan manajemen: (1) Karyawan merasakan kepercayaan terhadap kinerjanya; (2) Karyawan memperoleh dukungan dalam perusahaan terhadap kinerjanya.

b. Kejelasan: (1) Persepsi karyawan atas kejelasan aturan yang berlaku dalam perusahaan; (2) Persepsi karyawan atas norma yang berlaku dalam perusahaan.

c. Ekspresi diri: (1) Karyawan merasa bertanggung jawab atas pekerjaannya sendiri; (2) Dapat mengerjakan tugas tepat waktu.

d. Makna kontribusi yang dirasakan: (1) Perasaan bangga terhadap organisasi; (2) Persepsi karyawan terhadap derajat keloyalan anggota organisasi terhadap pencapaian tujuan organisasi.

e. Penghargaan: (1) Anggota organisasi merasa dihargai; (2) Dapat menyelesaikan tugas dengan baik. 
f. Tantangan: (1) Persepsi karyawan terhadap tingkat tekanan yang diberlakukan pada organisasinya; (2) Persepsi karyawan untuk meningkatkan kinerja.

\section{Komitmen Organisasi}

Menurut Wati (2013) komitmen organisasi adalah derajat sejauh mana keterlibatan seseorang dalam organisasinya dan kekuatan identifikasinya terhadap suatu organisasi tertentu. Komitmen organisasi juga ditandai dengan tiga hal, yaitu suatu kepercayaan yang kuat terhadap organisasi juga penerimaan terhadap tujuan- tujuan dan nilai-nilai sebuah organisasi, keinginan kuat untuk memelihara hubungan yang kuat dengan organisasi dan kesiapan serta kesediaan untuk menyerahkan usaha keras demi kepentingan organisasi. Berdasarkan pengertian tersebut pemerintah daerah yang memiliki komitmen terhadap organisasinya akan lebih dapat bertahan sebagai bagian dari organisasi dibandingkan dengan pemerintah daerah yang tidak memiliki komitmen terhadap organisasinya.

Konopaske, Ivancevichn dan Matteson (2015) menyatakan bahwa komitmen terhadap organisasi melibatkan tiga sikap, yaitu identifikasi dengan tujuan organisasi, perasaan keterlibatan dalam tugas-tugas organisasi, dan perasaan setia terhadap organisasi. Pekerjaan yang menjadi tugasnya dipahami sebagai kepentingan pribadi, dan memiliki keinginan untuk selalu loyal demi kemajuan organisasi.

Dimensi dan indikator Komitmen Organisasi

Menurut Luthans, Colquitt, Lepine, dan Wesson (2014) membagi komitmen organisasi menjadi tiga macam atas dasar:

a. Komitmen afektif (affective commitment). Sebagai keinginan untuk tetap menjadi anggota organisasi karena keterikatan emosional pekerja pada identifikasi dengan pelibatan dalam organisasi dimana seseorang karyawan akan berfikir mengenai hubungan mereka dengan organisasi dalam hal nilai dan kesatuan tujuan. Komitmen afektif (affective commitment) yang terdiri atas beberapa bagian seperti: Tingkat keinginan, hasrat untuk bertahan, bangga menjadi bagian perusahaan.

b. Komitmen kelanjutan (continuance commitment). Sebagai keinginan untuk tetap menjadi anggota organisasi karena kepedulian atas biaya yang berkaitan apabila meninggalkan organisasi didasari kerugian yang berhubungan dengan keluarnya karyawan dari organisasi. Komitmen kelanjutan (continuance commitment) yang terdiri atas : Sulit meninggalkan perusahaan meski karyawan sangat ingin melakukannya, karyawan dapat memenuhi kebutuhan hidup dengan bekerja diperusahaan ini dan sedikit pilihan bila meninggalkan perusahaan.

c. Komitmen normatif (Normative Commitment). Sebagai keinginan untuk tetap menjadi anggota organisasi karena merasa sebagai kewajiban yang menyangkut perasaan pekerja atas kewajiban untuk tetap tinggal dengan organisasi karena itu merupakan yang terbaik untuk dilakukan. Komitmen normatif (Normative Commitment) yang terdiri dari: Tingkat kebanggaan karyawan bekerja dalam perusahaan, tingkat pengorbanan karyawan dalam pekerjaan dan tingkat kesetiaan karyawan terhadap perusahaan.

\section{Hubungan Antara Variabel}

\section{Hubungan antara Disiplin Kerja dengan Produktivitas Kerja}

Untuk menciptakan produktivitasnya, maka disiplin kerja sangat mempengaruhi produktivitas kerja guru, karena disiplin kerja yang tinggi akan meningkatkan efektivitas dalam mencapai tujuan organisasi. Dilihat dari penelitian terdahulu, terdapat beberapa faktor yang berhubungan dengan produktivitas kerja dalam perusahaan, penelitian ini memusat kan pada variabel disiplin kerja. Adanya pengaruh positif dan signifikan dari disiplin kerja terhadap produktivitas kerja. Dilihat dari penelitian sebelumnya yang dilakukan oleh Rumondor (2013) dan Siswadi (2016). Dengan demikian, hipotesis pertama yang diajukan dalam penelitian ini adalah sebagai berikut:

H1: Disiplin kerja berpengaruh positif terhadap Produktivitas Kerja. 


\section{Hubungan antara Iklim Organisasi dengan Produktivitas Kerja}

Iklim organisasi yang terjadi dan terbangun dengan baik yang ditandai dengan praktek produktivitas kerja dalam suatu organisasi publik, dapat menimbulkan efek administrasi dan perilaku organisasi yang baik, serta menimbulkan efek positif pada meningkatnya produktivitas kerja. Dilihat dari penelitian terdahulu, terdapat beberapa faktor yang berhubungan dengan produktivitas kerja dalam perusahaan, penelitian ini memusat kan pada variabel iklim organisasi. Adanya pengaruh positif dan signifikan dari iklim organisasi terhadap produktivitas kerja. Dilihat dari penelitian sebelumnya yang dilakukan oleh Faridayanti, Wahyudi, Wardiningsih (2017) dan Widodo (2015). Dengan demikian, hipotesis kedua yang diajukan dalam penelitian ini adalah sebagai berikut:

H2: Iklim organisasi berpengaruh positif terhadap Produktivitas Kerja.

\section{Hubungan antara Komitmen Organisasi dengan Produktivitas Kerja}

Kurangnya komitmen organisasi memberikan efek negatif pada produktivitas karyawan yang sebagian besar berkontribusi besar terhadap kegagalan organisasi yang tidak mencapai tujuan organisasi. Dilihat dari penelitian terdahulu, terdapat beberapa faktor yang berhubungan dengan produktivitas kerja dalam perusahaan, penelitian ini memusat kan pada variabel komitmen organisasi. Adanya pengaruh positif dan signifikan dari komitmen terhadap produktivitas kerja. Dilihat dari penelitian sebelumnya yang dilakukan oleh Osa, Amos (2014) dan Nengsih (2015). Dengan demikian, hipotesis ketiga yang diajukan dalam penelitian ini adalah sebagai berikut:

H3: Komitmen organisasi berpengaruh positif terhadap Produktivitas Kerja

\section{Kerangka Konseptual Dan Hipotesis}

Berdasarkan kajian pustaka dan penelitian terdahulu maka peneliti merumuskan rerangka pemikiran sebagai berikut:

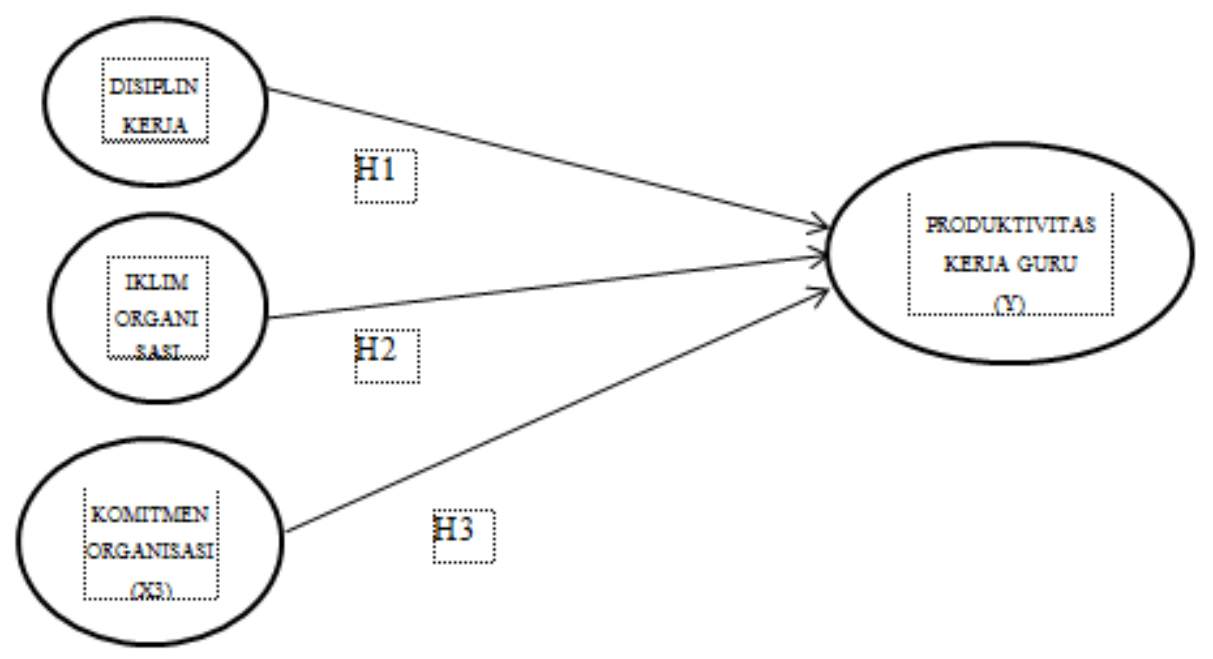

Gambar 1. Kerangka Berpikir

H1 : Disiplin Kerja berpengaruh positif Terhadap Produktivitas Kerja Guru.

H2 : Iklim Organisasi berpengaruh positif Terhadap Produktivitas Kerja Guru.

H3 : Komitmen Organisasi berpengaruh positif Terhadap Produktivitas Kerja Guru.

\section{METODE PENELITIAN}

Waktu dan Tempat Penelitian 
Penelitian ini mulai dilakukan pada bulan Desember 2018 sampai dengan bulan Juni 2019 hingga tercukupi kebutuhan data dan informasi. Penelitian ini dilaksanakan secara bertahap dengan menggunakan prasurvey, mulai dari pendahuluan, pengajuan proposal, pengajuan surat izin penelitian, konsultasi hingga pembuatan kuesioner serta pengolahan data penyusunan skripsi. Penelitian ini dilakukan di Sekolah Dasar Islam Assidiqiyah Ciledug Kota Tangerang. Jalan Hos Cokroaminoto No 2 Sudimara Barat Ciledug, Kota Tangerang.

Penelitian ini merupakan penelitian untuk mengetahui pengaruh variabel independent (prdiktor) yaitu Disiplin kerja, Iklim Organisasi, Komitmen Organisasi terhadap satu variabel dependent (kriteria) yaitu Produktivitas Kerja. Dalam hal ini penelitian bertujuan untuk mengetahui pengaruh Disiplin Kerja, Iklim Organisasi dan Komitmen Organisasi Terhadap Produktivitas Kerja Guru di Sekolah Dasar Islam Assidiqiyah Ciledug Kota Tangerang.

\section{Populasi dan Sampel Penelitian}

Menurut Sekaran, Bougie (2017) populasi adalah keseluruhan sekelompok orang, kejadian, atau hal yang menarik peneliti untuk melakukan investigasi atau membuat sebuah opini berdasarkan pada statistik sampel. Sedangkan menurut Ghozali (2016) populasi adalah keseluruhan orang, peristiwa, atau apa yang menjadi perhatian peneliti untuk membuat inferensi. Populasi dalam penelitian ini adalah guru Sekolah Dasar Islam Assidiqiyah Ciledug Kota Tangerang yang berjumlah 56 guru. Jadi jumlah populasi sebanyak 56 orang. Menurut Ghozali (2016) sampel adalah bagian dari jumlah populasi yang berisi beberapa anggota dalam populasi atau elemen yang akan membentuk sampel. Sedangkan menurut Sekaran, Bougie (2017) sampel adalah sebagian dari seluruh jumlah populasi yang dipilih sehingga dapat menarik kesimpulan yang dapat diambil terhadap populasi yang diminati. Sampel pada penelitian ini adalah 56 guru.

\section{Metode Analisis Data}

Partial Least Square merupakan metode analisis Component / Variance Based Structural Equation Modeling dimana dalam pengelohan data menggunakan program versi 3.0. PLS (Partial Least Square) adalah model alternatif dari covariance based SEM. PLS dimaksudkan untuk causal-predictive analysis dalam situasi kompleksitas yang tinggi dan dukungan teori yang rendah (Ghozali, 2015)..

\section{HASIL DAN PEMBAHASAN}

\section{Deskripsi Responden}

Karakteristik responden digunakan untuk menguraikan deskripsi identitas responden menurut sampel penelitian yang telah ditetapkan salah satu tujuan dengan deskripsi karakteristik responden adalah memberikan gambaran yang menjadi sampel dalam penelitian. Adapun sampel pada penelitian ini dilakukan kepada 56 responden, karakteristik dikelompkkan berdasarkan jenis kelamin, usia, pendidikan terakhir dan lama bekerja. Oleh karena itu uraian mengenai karakteristik responden dapat diuraikan sebagai berikut:

Tabel 1. Deskripsi Berdasarkan Usia

\begin{tabular}{ccc}
\hline & Frequency & Precent \\
\hline Valid $21-30$ tahun & 7 & $12,5 \%$ \\
\hline $30-40$ tahun & 20 & $35,7 \%$ \\
\hline $41-50$ tahun & 20 & $35,7 \%$ \\
\hline$>50$ tahun & 9 & $16,1 \%$ \\
\hline Total & 56 & $100 \%$ \\
\hline
\end{tabular}

Sumber: Data Primer diolah, 2019. 
Berdasarkan hasil data yang diperoleh didapati bahwa jumlah terbanyak ada pada usia 30 - 40 tahun dan 41 - 50 tahun yang mencapai 20 guru atau dengan jumlah presentasi $35,7 \%$ dan jumlah terendah ada pada usia 21 - 30 tahun yang mencapai 7 guru atau dengan jumlah presentasi $12,5 \%$.

Tabel 2.Deskripsi Berdasarkan Jenis Kelamin

\begin{tabular}{lllcl}
\hline & & & Frequency & Precent \\
\hline Valid & Laki-laki & 23 & $41,1 \%$ & \\
\hline & Perempuan & 33 & $58,9 \%$ & \\
\hline Total & 56 & $100 \%$ & \\
\hline
\end{tabular}

Sumber: Data Primer diolah, 2019.

Berdasarkan hasil data yang didapati bahwa perempuan memiliki jumlah terbanyak yakni 33 guru atau dengan jumlah presentasi 58,9 \% dan laki-laki memiliki jumlah terendah yakni 23 guru atau dengan jumalh presentasi $41,1 \%$. Dari data tersebut dapat disimpulkan bahwa guru di Sekolah Dasar Islam Assidiqiyah Ciledug lebih di dominasi oleh perempuan.

Tabel 3. Deskripsi Berdasarkan Pendidikan

\begin{tabular}{|c|c|c|c|c|}
\hline & & & Frequency & Precent \\
\hline \multirow[t]{5}{*}{ Valid } & SMA/SM & 4 & $7,1 \%$ & \\
\hline & Diploma (D1,2,3) & 19 & $33,9 \%$ & \\
\hline & $\mathrm{S} 1$ & 31 & $55,4 \%$ & \\
\hline & $\mathrm{S} 2$ & 2 & $3,6 \%$ & \\
\hline & Total & 56 & $100 \%$ & \\
\hline
\end{tabular}

Sumber: Data Primer diolah, 2019.

Berdasarkan hasil data yang didapati bahwa tingkat pendidikan S1 memiliki jumlah terbanyak yakni 31 guru dengan jumlah presentasi 55,4 \% dan tingkat pendidikan S2 memiliki jumlah terendah yakni 2 guru dengan jumlah presentasi 3,6\%.

Tabel 4. Deskripsi Berdasarkan Lama Bekerja

\begin{tabular}{ccc}
\hline & Frequency & Precent \\
\hline Valid $1-5$ tahun & 8 & $14,3 \%$ \\
\hline $6-10$ tahun & 20 & $35,7 \%$ \\
\hline $11-15$ tahun & 16 & $28,6 \%$ \\
\hline $16-20$ tahun & 10 & $17,9 \%$ \\
\hline$>20$ tahun & 2 & $3,6 \%$ \\
\hline Total & 56 & $100 \%$ \\
\hline
\end{tabular}

Sumber: Data Primer diolah, 2019.

Berdasarkan hasil data yang didapati bahwa jumlah terbanyak lama bekerja adalah $6-10$ tahun yakni 20 guru atau dengan jumlah presentasi 35,7 \% dan jumlah terendah lama bekerja adalah $>20$ tahun yakni 2 guru atau dengan jumlah presentasi 3,6\%.

\section{Uji Validitas}


Tabel 5. Hasil Pengujian Convergent Validity

\begin{tabular}{cccc}
\hline Variabel & Indikator & Outer & Koterangan \\
\cline { 3 - 4 } & & & \\
\hline $\begin{array}{c}\text { Disiplin } \\
\text { Kerja }\end{array}$ & DK3 & 0.703 & Valid \\
\hline (X1) & DK4 & 0,900 & Valid \\
\hline & DK5 & 0.907 & Valid \\
\hline & DK6 & 0.762 & Valid \\
\hline $\begin{array}{c}\text { Iklim } \\
\text { Organisasi }\end{array}$ & IO1 & 0.769 & Valid \\
\hline (X2) & IO3 & 0,834 & Valid \\
\hline & IO4 & 0,826 & Valid \\
\hline $\begin{array}{c}\text { Komitmen } \\
\text { Organisasi }\end{array}$ & KO3 & 0,821 & Valid \\
\hline (X3) & KO9 & 0.913 & Valid \\
\hline $\begin{array}{c}\text { Produkvitas } \\
\text { Kerja }\end{array}$ & PK5 & 0.869 & Valid \\
\hline (Y) & PK6 & 0.723 & Valid \\
\hline & PK8 & 0,800 & Valid \\
\hline Sumber: Outpun SmartPS & 2019. &
\end{tabular}

Sumber: Output SmartPLS 3, 2019.

Berdasarkan Tabel 5 dengan melihat hasil melihat hasil output korelasi antara indikator dengan konstruknya seperti terlihat pada gambar hasil Pengujian Convergent Validity, sudah di katakana baik karena sudah melebihi realibilitas yang baik dengan nilai melebihi 0,70 sedangkan loading factor 0,50 sampai 0,60 dapat dianggap cukup.

\section{Uji Reabilitas}

Tabel 6. Hasil Matrix Pengujian Composite Reliability

\begin{tabular}{lc}
\hline \multicolumn{1}{c}{ Variabel } & $\begin{array}{c}\text { Composite } \\
\text { Reliability }\end{array}$ \\
\hline Disiplin Kerja & 0.892 \\
\hline Iklim Organisasi & 0.886 \\
\hline Komitmen Organisasi & 0.885 \\
\hline Produktivitas Kerja & 0.819 \\
\hline Sumber: Output SmartPLS 3, 2019.
\end{tabular}

Apabila seluruh nilai variabel laten memiliki nilai composite reliability maupun cronbac alpha $\geq 0,7$ hal itu berarti bahwa konstruk memiliki reliabilitas yang baik atau Apabila seluruh nilai variabel laten memiliki nilai composite reliability maupun cronbach alpha $\geq 0,7$ hal itu berarti bahwa konstruk

Tabel 7. Hasil Matrix Pengujian Cronbach's Alpha

\begin{tabular}{cc}
\hline Variabel & $\begin{array}{c}\text { Cronbach's } \\
\text { Alpha }\end{array}$ \\
\hline Disiplin Kerja & 0.839 \\
\hline
\end{tabular}




\begin{tabular}{lc} 
Iklim Organisasi & 0.831 \\
\hline Komitmen Organisasi & 0.743 \\
\hline Produktivitas Kerja & 0.667 \\
\hline Sumber: Output SmartPLS 3, 2019.
\end{tabular}

Seluruh nilai variabel laten memiliki nilai composite reliability $\geq 0,70$, tetapi tidak demikian dengan hasil pengujian cronbach's alpha, karena ada satu nilai variabel laten yang memiliki nilai cronbach's alpha $\geq 0,70$.

\section{Pembahasan}

\section{Disiplin Kerja terhadap Produktivitas Kerja}

Hasil uji hipotesis dan hasil temuan beberapa penelitian terdahulu dapat disimpulkan bahwa faktor Disiplin Kerja dapat memberikan pengaruh positif terhadap Produktivitas Kerja secara signifikan. Guru di Sekolah Dasar Islam Assidiqiyah Ciledug merasa produktivitas dapat dilaksanakan sesuai dengan yang diharapkan oleh yayasan jika bekerja secara disiplin.

\section{Iklim Organisasi terhadap Produktivitas Kerja}

Dari hasil uji hipotesis dan hasil temuan beberapa penelitian terdahulu dapat disimpulkan bahwa faktor Iklim Organisasi dapat memberikan pengaruh positif terhadap Produktivitas Kerja secara signifikan. Guru di Sekolah Dasar Islam Assidiqiyah Ciledug merasa produktivitas dapat dipengaruhi secara signifikan oleh iklim yang dirasakan selama bekerja.

\section{Komitmen Organisasi terhadap Produktiivtas Kerja}

Hasil uji hipotesis dan hasil temuan beberapa penelitian terdahulu dapat disimpulan bahwa faktor Komitmen Organisasi dapat memberikan pengaruh positif terhadap Produktivitas Kerja secara signifikan. Guru di Sekolah Dasar Islam Assidiqiyah Ciledug merasa produktivitas dapat dipengaruhi secara signifikan oleh komitmen yang diberikan yayasan selama bekerja. hasil uji hipotesis dan hasil temuan beberapa penelitian terdahulu dapat disimpulan bahwa faktor Komitmen Organisasi dapat memberikan pengaruh positif terhadap Produktivitas Kerja secara signifikan. Guru di Sekolah Dasar Islam Assidiqiyah Ciledug merasa produktivitas dapat dipengaruhi secara signifikan oleh komitmen yang diberikan yayasan selama bekerja.

\section{KESIMPULAN DAN SARAN \\ Kesimpulan}

Berdasarkan hasil penelitian dan pembahasan pada bab sebelumnya, mengenai pengaruh Disiplin Kerja, Iklim Organisasi dan Komitmen Organisasi terhadap Produktivitas Kerja Guru maka kesimpulan dalam penelitian ini sebagai berikut:

1. Disiplin Kerja berpengaruh positif dan siginifikan terhadap Produktivitas Kerja, artinya menunjukan bahwa semakin meningkat Disiplin Kerja yang dimiliki guru, maka semakin meningkat pula produktivitas kerja.

2. Iklim Organisasi berpengaruh positif dan signifikan terhadap Produktivitas Kerja, artinya menunjukan bahwa semakin baik Iklim Organisasi tercipta maka semakin baik pula Produktivitas Kerja.

Komitmen Organisasi berpengaruh positif dan signifikan terhadap Produktivitas Kerja, artinya menunjukan bahwa semakin tinggi Komitmen Organisasi yang dimiliki guru, maka semakin tinggi pula Produktivitas Kerja 
Saran

Berdasarkan hasil kesimpulan diatas, maka dapat diberikan beberapa saran untuk pihak pihak yang bersangkutan sebagai berikut:

1. Saran untuk Sekolah Dasar Islam Assidiqiyah Ciledug

a. Pada variabel Disiplin Kerja nilai jawaban responden yang paling rendah adalah indikator DK7 $(3,607)$ yaitu: "Karyawan fokus dalam bekerja". Artinya sebagian responden belum merasa fokus dalam melakukan pekerjaan yang dilakukan. Oleh karena itu saran yang bisa dijadikan pertimbangan adalah dengan memperbaiki dan meningkatkan situasi bekerja lebih kondusif lagi, seperti membuat poster pada setiap depan ruangan guru untuk memberitahukan bahwa area tersebut tidak boleh berisik. Hal ini diharapkan demi menunujang kegiatan bekerja agar lebih fokus lagi.

b. Pada variabel Iklim Organisasi nilai jawaban responden yang paling rendah adalah indikator IO6 $(3,804)$ yaitu: "Karyawan dapat mengerjakan tugas tepat waktu". Artinya sebagian responden belum merasa tepat waktu dalam mengerjakan tugas - tugas. Oleh karena itu saran yang bisa dijadikan pertimbangan adalah memperbaiki jam operasional karyawan yang belum dirasa efektif serta menegakkan hukuman atau sanksi yang tegas kepada karyawan yang tidak mengerjakan tugas dengan tepat waktu.

c. Pada variabel Komitmen Organisasi nilai jawaban responden yang paling rendah adalah indikator KO3 $(3,625)$ yaitu: "Karyawan bangga menjadi bagian dari Yayasan". Artinya sebagian responden belum merasa bangga telah menjadi bagian dari Yayasan walaupun sudah bekerja cukup lama. Oleh karena itu saran yang bisa dijadikan pertimbangan adalah pihak Sekolah Dasar Islam Assidiqiyah Ciledug harus meningkatkan rasa bangga karyawan karena telah menjadi bagian dari yayasan, yaitu salah satunya dengan meningkatkan benefit yang membuat karyawan merasa bangga atas benefit yang diterima, benefit yang dapat diberikan berupa bonus, ataupun reward terhadap karyawan yang berprestasi, dan lainnya.

2. Saran untuk Penelitian Selanjutnya

a. Dari hasil penelitian ini, disarankan untuk penelitian selanjutnya agar bisa meneliti lebih lanjut dengan objek yang berbeda serta melibatkan lebih banyak responden dalam melakukan penelitian yang dapat mempengaruhi Produktivitas Kerja,

b. Dari hasil penelitian ini, disarankan untuk penelitian selanjutnya agar bisa meneliti lebih lanjut dengan menambahkan kembali variabel yang belum digunakan dalam penelitian ini, seperti variabel Semangat Kerja, Motivasi Kerja, Kepuasan Kerja, dan Struktur Organisasi

\section{DAFTAR PUSTAKA}

Abdullah, D. (2017). "Pengaruh Komitmen Organisasional dan Lingkungan Psikologis terhadap Produktivitas Kerja Karyawan Bank BJB cabang Majalengka”. Jurnal Ilmiah Manajemen dan Akuntansi, 4 (1), 2356-3923.

Afia Hidayat, A., Joko Sugiharjo, R., \& Dhyan Parashakti, R. (2019). Mengelola Sumber Daya Manusia di Era Revolusi Industri 4.0, Wahana Resolusi, Yogyakarta.

Aryansyah, I. \& Setyanti Kusumaputri, E. (2013). "Iklim Organisasi dan Kualitas Kehidupan Kerja Karyawan". Humanitas, 10 (1), 76-86.

Dessler, G. (2015). Manajemen Sumber Daya Manusia, Edisi Empat Belas, Penerbit Salemba Empat, Jakarta.

Dhyan Parashakti, R., Laurencia, S.K., \& Septiani, J. (2017). "Determinants of Employee's Discipline and Motivation: Evidence from Banks in Indonesia". International Journal of Economic Perspective, 11 (1), 1598-1607.

Dunggio, M. (2013). "Semangat dan Disiplin Kerja terhadap Produktivitas Kerja Karyawan pada PT Jasa Raharja Persero cabang Sulawesi”. Jurnal EMBA, 1 (4), 523-533.

Faridayanti, D., Wahyudi, A., \& Sri Wardiningsih, S. (2017). "Pengaruh Iklim Organisasi, Pelatihan dan Kemampuan Kerja terhadap Produktivitas Kerja (Studi pada Perawat Rumah Sakit Jiwa Daerah Surakarta)". Jurnal Sumber Daya Manusia, 11 (2), 238-250.

Ghozali, I. \& Laten, H. (2015). Partical Least Squares: Konsep Teknik Dan Aplikasi Menggunakan Program SmartPLS 3.0, Edisi 2, Universitas Deponegoro. Semarang. 
Ghozali, I. (2016). Desain Penelitian Kuantitatif \& Kualitatif: Untuk Akutansi, Bisnis, dan Ilmu Sosial Lainnya, Universitas Deponegoro. Semarang.

Goddy Osa, A. \& Oluwafemi Amos, I. (2014). "The impact of organizational commitment on employees productivity a case study of Nigeria Brewery". PLC Journal of research in business management. 2 (9), 107-122.

Labudo, Y. (2013). "Disiplin Kerja dan Kompensasi pengaruhnya terhadap Produktivitas Karyawan”. Jurnal EMBA, 1 (3), 55-62.

Mathis, R.L., Jackson, J.H., Valentine, S.R., \& Meglich, P.A. (2017). Human Resource Management, Fifteenth Edition, Cengage Learning, Boston, USA.

Mustafa Elqadri, Z., Tri Wijayati Wardoyo, D., \& Priyono. (2015). "The Influence of Motivation and Discipline Work against Employee Work Productivity Tona'an Markets: Review of European Studies". Published by Canadian Center of Science and Education, 7 (12), 5966, DOI:10.5539/res.v7n12p59.

Nazar Almasri, M. (2016). "Manajemen Sumber Daya Manusia: Implementasi Dalam Pendidikan Islam”. Jurnal Penelitian Sosial Agama, 19 (2), 134-151.

Nurma Hastuti, D., Dewi, L., \& Suhardini, D. (2016). "Pengaruh Iklim Organisasi terhadap Produktivitas Kerja Tenaga Perpustakaan pada CISRAL". Universitas Padjadjaran, 6 (1), 17-30.

Pratiwi, S. (2015). "Pengaruh motivasi, iklim kerja dan tingkat pendidikan terhadap produktivitas kerja guru SMK Saraswati Sukoharjo”. Jurnal Manajemen Sumber Daya Manusia. 9 (1), 21-28.

Sedarmayanti. (2015). Tata Kerja dan Produktivitas Kerja, CV Mandar Maju, Bandung.

Sekaran, U., Bougie, R. (2017a). Metode Penelitian Untuk Bisnis: Pendekatan Pengembangan Keahlian, Edisi Enam, Buku Kesatu, Penerbit Salemba Empat, Jakarta.

Sekaran, U., Bougie, R. (2017b). Metode Penelitian Untuk Bisnis: Pendekatan Pengembangan Keahlian, Edisi Enam, Buku Kedua, Penerbit Salemba Empat, Jakarta.

Septia Nengsih, V. (2015). "Pengaruh Kepemimpinan, Kompensasi dan Komitmen Organisasi terhadap Produktivitas Kerja Marketing PT Asuransi Bumi Putra". Jom FEKON, 2 (2), 112.

Siswadi, Y. (2016). "Pengaruh Pelatihan dan Disiplin terhadap Produktivitas Kerja Karyawan pada PT Jasa Marga Cabang Balmera, Medan”. Jurnal Ilmiah Manajemen dan Bisnis, 17 (1), 125-137.

Syarif, D. (2015). Teori-teori Manajemen dan Organisasi. Diunduh dari: http://theorymanajemendanorganisasi.blogspot.com/2015/12/iklim-organisasi.html. pada 26 Oktober 2018.

Syarif, D. (2015). Teori-teori Manajemen dan Organisasi. Diunduh dari: http://theorymanajemendanorganisasi.blogspot.com/2015/12/komitmenorganisasi_18.html. pada 26 Oktober 2018.

Usman, I. (2016). "Pengaruh disiplin kerja terhadap produktivitas kerja karyawan PT Allo Jaya di Bontang". E-journal Administrasi Bisnis. 4 (3), 911-922.

Wentri Rumondor, V. (2013). "Motivasi, disiplin kerja dan kepemimpinan terhadap produktivitas kerja pada badan keegawaian dan diklat daerah Minahasa Selatan". Jurnal EMBA. 1 (4), 1042-1052.

Wibowo. (2014). Manajemen Kinerja Edisi Keempat, Rajawali Pers, Depok.

Widodo. (2015). "Pengaruh Iklim Organisasi dan Pelaksanaan Program K3 terhadap Produktivitas Kerja PT Bormindo Nusantara". Jurnal Manajemen Bisnis Krisnadwipayana, 3 (3), 2338-4794.

Yusuf, B. (2015). Manajemen Sumber Daya Manusia di Lembaga Keuangan Syariah, Depok. Jawa Barat. 